Mr LJUBINKA ŠKODRIĆ, viši arhivist

Arhiv Srbije

UDK 94:176.5(497.11)"1941/1944"(093.2)

Beograd, Karnegijeva 2

392.65(497.11)"1941/1944"(093.2)

\title{
„HORIZONTALNA KOLABORACIJA“ - INTIMNE VEZE ŽENA SA NEMAČKIM OKUPATOROM U SRBIJI 1941-1944.
}

APSTRAKT: Članak se bavi okolnostima pod kojima su žene stupale u intimne veze sa nemačkim okupatorom u Srbiji tokom Drugog svetskog rata. Analizirani su politika i odnos antifašističkih pokreta prema takvim ženama, kao i društveni značaj koji su te veze imale.

Ključne reči: Drugi svetski rat, Srbija, okupator, žene, intimne veze

Poraz u ratu i nacistička okupacija u pokorenim evropskim zemljama tokom Drugog svetskog rata simbolički su označili neuspeh borbene, muške snage nacije. Porazom domaćeg maskuliniteta seksualnost je postavljena kao smernica u odnosu žena prema okupatoru. „Horizontalna kolaboracija" ${ }^{1}$ je pojava koja podrazumeva seksualnu ili ljubavnu vezu sa okupatorom, odnosno intimnu bliskost sa neprijateljem, zbog čega taj čin nosi specifičnu težinu iako nema uticaja na ratni ishod. Ovaj vid kolaboracije se razlikuje od drugih pošto je jedini vid isključivo ženske kolaboracije pa, iako zakonski nije prekršaj, predstavlja pretnju nacionalnom jedinstvu. ${ }^{2}$

Može se razlikovati nekoliko tipova intimnih veza sa okupatorom od prostitucije, diskretnih veza, druženja sa grupama nemačkih vojnika do veza koje su nastale kao proizvod simpatija za nacističku ideologiju. Nemački vojnici, ovenčani slavom ratnih pobednika i materijalno obezbe-

${ }^{1} \mathrm{U}$ francuskoj istoriografiji u kojoj je nastao pojam „horizontalna kolaboracija“ koristi se i blaži termin „sentimentalna kolaboracija“ („collaboration sentimentale“). - Richard Vinen, The Unfree French. Life under the Occupation, Penguin books, 2007, 176.

${ }^{2}$ „Horizontal collaboration ` became one of the most unbearable types of collaboration, not on account of its immediate effect, which was negligible, but because it represented the absolute defeat of France“. „„Horizontalna kolaboracija“ je postala jedna od najnepodnošljivijih vrsta kolaboracije, ne zbog svojih neposrednih efekata, koji su bili zanemarljivi, već zato što je predstavljala apsolutni poraz Francuske“. - Fabrice Virgili, Shorn Women. Gender and Punishment in Liberation France, Berg, Oxford, New York, 2002, 239. 
đeni, posedovali su moć da zavedu, a veze sa njima mogle su biti vid zaštite i strategija opstanka sa ciljem pristupa hrani. ${ }^{3}$ Za mnoge žene takva veza je predstavljala mogućnost da se dopre do nedostupnih sredstava, ali i vid zabave i beg od tmurne svakodnevice. ${ }^{4}$ Veze sa okupatorom mogle su da ponude ženama iz nižih slojeva kratkoročnu afirmaciju i društveno uzdizanje. ${ }^{5}$ Ipak, u intimnim vezama sa okupatorskim vojnicima nije bilo isključivo interesa, već i emotivnih sadržaja. Neki parovi su se zaljubili, ali su veze sa obe strane uglavnom značile samozavaravanje. I, bez obzira na motivaciju, predstavljale su u osnovi nejednak odnos.

U pokorenoj Evropi, u oblastima sa blažim režimom okupacije, kao i $\mathrm{u}$ onima u kojima je postojao veliki broj nemačkih vojnika i gde je ostatak stanovništva bio u bliskim odnosima sa okupatorom, postojala je i veća tolerancija prema ponašanju žena. U Norveškoj i Danskoj blag režim okupacije i brojnost nemačkih trupa predstavljali su značajan faktor velike brojnosti stupanja žena u veze sa okupatorom. ${ }^{6} \mathrm{Na}$ veze francuskih žena sa okupatorom uticala je činjenica da se veliki broj Francuza nalazio u ratnom zarobljeništvu. Istoričari procenjuju da je iz veza nemačkih vojnika sa Francuskinjama rođeno 50.000-75.000 dece, ali novija istraživanja podižu taj broj do $200.000 .^{7}$

Na teritorijama sa strogim režimom okupacije intimne veze sa okupatorom imale su naročitu težinu pošto su bile povezane sa sprovođenjem rasne politike. U Češko-moravskom protektoratu intimni odnosi sa okupatorom su potpomagali program germanizacije. ${ }^{8} \mathrm{~S}$ druge strane, na okupira-

${ }^{3}$ U Grčkoj koja je bila izmorena glađu, stupanje u intimne veze sa okupatorom za mnoge žene je predstavljalo način da prežive. Majka i sestra Marije Kalas snabdevale su porodicu hranom tako što je majka bila u intimnim odnosima sa jednim italijanskim oficirom, a sestra sa bogatim čovekom. - Elizabet Abot, Istorija ljubavnica, Beograd 2006, 350.

4 „Bilo je „posrnulih žena“ u sprezi sa okupatorom, radi sitnih materijalnih prednosti i iz teške površnosti i lakomislenosti." - Milorad Bertolino, Sećanje na Šabac i Loznicu, Šabac 1981, 95.

${ }^{5}$ R. Vinen, $n . d ., 179$.

${ }^{6}$ Tokom 1942. jedan ilegalni danski list je tvrdio kako u šetnji Kopenhagenom nije moguće napraviti nekoliko koraka, a da se ne naiđe na nemačkog vojnika sa devojkom u zagrljaju. U Norveškoj je rođeno oko 9.000 dece iz veza sa nemačkim vojnicima, a skoro 50.000 Norvežanki bilo je u vezama sa nemačkim vojnicima što predstavlja značajan procenat u populaciji od 3 miliona stanovnika. Ovaj procenat je nešto niži u Danskoj gde je bio i manji broj nemačkih trupa. - Surviving Hitler and Mussolini. Daily Life in Occupied Europe, Edited by Robert Gildea, Olivier Wieviorka and Anett Warring, Berg, Oxford, New York, 2006, 91.

${ }^{7}$ R. Vinen, $n$. d., 160.

${ }^{8}$ Benjamin Frommer, Denouncers and Fraternizers: Gender, Collaboration, and Retribution in Bohemia and Moravia during World War II and After, Gender and War in TwentiethCentury Eastern Europe, Edited by Nency M. Wingfield and Maria Bucur, Indiana University Press, Bloomington 2006, 121. 
nim sovjetskim teritorijama, nemačka komanda je uzaludno nastojala da spreči seksualne kontakte vojnika sa, kako je smatrano, rasno inferiornim slovenskim stanovništvom. Od kraja 1942. nacisti počinju da ispoljavaju posebno zanimanje za decu rođenu iz veza nemačkih vojnika na Istočnom frontu, a vršene su procene da će godišnje broj te dece prevazići jedan milion. ${ }^{9}$

Motiv ženske preljube sa okupatorom predstavljao je bolnu temu $\mathrm{u}$ srpskom društvu još od Prvog svetskog rata, a svoj odraz našao je i u književnosti. Advokat i književnik, a zatim i ideolog ravnogorskog pokreta, Dragiša Vasić je u privatnom životu doživeo sličnu sudbinu. ${ }^{10}$ Autor je pripovetke $U$ gostima u kojoj opisuje posleratni alkoholizam i depresiju ratnog veterana opterećenog ženinom preljubom tokom okupacije u Prvom svetskom ratu. ${ }^{11}$ Osuda stupanja u ljubavne veze sa okupatorom spominje se i kod drugih autora, ali su postojali i drugi aspekti sagledavanja tog čina. Milutin Milanković je zabeležio da je beogradska javnost sa zahvalnošću posmatrala delatnost prijateljice grofa Salis Sevisa, austrijskog guvernera okupirane Srbije, koja je svoj položaj koristila i kao način da mnogima pomogne. ${ }^{12}$

Stupanje žena u intimne odnose sa okupatorom bilo je očekivano $u$ javnosti već na samom početku okupacije Srbije u Drugom svetskom ratu. Ovim očekivanjima je pogodovala činjenica da je postojao veliki broj žena čiji su se muževi našli u ratnom zarobljeništvu. Komesarijat Ministarstva

${ }^{9} \mathrm{U}$ slučajevima kada su sovjetske žene ostajale u drugom stanju sa nemačkim vojnicima morale su da prođu rasnu inspekciju da bi se utvrdilo da li su pogodne za germanizaciju što je podrazumevalo procenjivanje izgleda, osobina, porekla i seksualne istorije, ali je postojalo generalno uverenje da su u pitanju rasno nepoželjne žene, a čak ih je i sama činjenica da su stupile u vezu sa neprijateljem činila nepoželjnim. - Regina Mühlhüuser, Between 'Racial Awareness' and Fantasies of Potency in the Occupied Territories of the Soviet Union, 1942-1945, Brutality and Desire. War and Sexuality in Europes`s Twentieth Century, Edited by Dagmar Herzog, Palgrave Macmillan, New York, 2009, 211.

${ }^{10}$ Vasić je bio oženjen ćerkom Stojana Ribarca, vođe Liberalne stranke. Supruga mu je po povratku kući posle Prvog svetskog rata saopštila da se zaljubila u jednog austrougarskog oficira i da želi razvod braka. - Miladin Vukosavljević, Miroslav Krleža i Dragiša Vasić (Skica za studiju), Život i delo Dragiše Vasića, Zbornik radova, Gornji Milanovac 2008, 352.

11 „Pa lepo, sami kažite: ko je siguran u ženu za vreme okupacije? Ajd recite sami. U svakoj kući oficir, je 1 te? Jedna kuća, brate. Stari pospe, deca pospe, a negde je i bez dece, nema govora. Tu ti je jedini gospod bog svedok. A kad si se vratio ona ne može da ti se napriča o poštenju. I sve druge ne valjaju samo ona poštena. Ona ni za jednu nije, veli, sigurna. A ti je gledaš, obrćeš, meriš, misliš: deca, bruka, razvod košta, da se ženiš ponova ne ide; nema govora - i onda slegneš ramenima, zažmuriš, pomisliš što je ko dobio neka nosi i ideš svaki dan na rakiju, samo idućeg dana piješ po jednu čašicu više." - Utuljena baština, Antologija (cenzurisanih) pripovedaka, I, priredio Gojko Tešić, Beograd 1990, 42.

${ }^{12}$ Njena delatnost posmatrana je sa konstatacijom: „Grešnica je - ali dobročiniteljka!" - Milutin Milanković, Sećanja, Beograd 2005, 379. 
prosvete je već u julu 1941. zabranio davanje pozorišne predstave „Žena u pozadini“ zbog vulgarnosti, ismevanja i netaktičnosti u sadržaju komada koji je govorio o nemoralnom ponašanju žene čiji je muž u zarobljeništvu. ${ }^{13}$ Stupanje u seksualne veze sa okupatorom predstavljalo je čestu i popularnu temu u domaćoj javnosti, pa je opevano i od strane „narodnog pesnika“ Vlaje iz Glibovca koji je svojim pesmama zabavljao putnike po vozovima. Pored osude nemoralnosti same pojave, kao povod za osudu u pesmi se spominju i zanemarivanje dece, ali i koristoljublje, što ukazuje na vrstu prostitucije. ${ }^{14}$

Prvi susret sa okupatorskim vojnicima ostavio je na pripadnice ženskog pola u Srbiji pozitivan utisak. Nemački vojnici bili su uglavnom mladići koji su se pristojno i korektno ponašali, naročito prema ženama. ${ }^{15}$ Takvo stanje se, međutim, vrlo brzo izmenilo. Pošto su najbolje nemačke snage upućene na Istočni front, u Srbiji su red održavale malobrojne nemačke trupe uglavnom sastavljene od starijeg ljudstva, nedovoljno disciplinovanog, sklonog opijanju i neuljudnom ponašanju prema stanovništvu. ${ }^{16}$

Osim vojnih snaga, stanovništvo se susretalo i sa činovnicima nemačkog okupacionog aparata čije je držanje uglavnom bilo arogantno i nadmeno, što je posebno bila odlika predstavnika bezbednosnih okupacionih organa. Policijske činovnike većinom su činili nemački službenici koji često nisu imali odgovarajuću stručnu spremu za poslove koje su obavljali, a uživali su u pogodnostima nameštenja koje ih je držalo daleko od fronta i većih ratnih okršaja. U privatnom životu bili su dobro situirani, većinom su imali ljubavnice i voleli su da konzumiraju alkohol. ${ }^{17}$ Slično je bilo i u drugim okupacionim službama. Nemačko železničko osoblje koje je boravilo u Nišu, izuzev šefa stanice, imalo je ljubavne veze sa lokalnim ženama, a neki od njih su svoje prijateljice vodili u posete kući u Nemačku. ${ }^{18}$

U srpskoj javnosti je bilo primećeno da su nemački vojnici „neobično korektni, naročito prema ženskom svetu“ ${ }^{19}$ Vladalo je mišljenje da se

${ }^{13}$ Arhiv Srbije (AS), G-3 (Ministarstvo prosvete i vera 1941-1944), f. 62, 35$16-41$.

14 „Sa Madžarom pa i sa Nemca/A u sobu da ju plaču deca/Psi laju pa jednako ržu/Oni meso u tiganju pržu“. - „Pesme invalida Vlaje“ postojale su i u štampanom izdanju, a zbog njih je bio pritvoren u logoru na Banjici. - Nenad J. Ristić, Džumbusana u Centralu Pozorišni život u Palanci (Smed) 1941-1944, Smederevska Palanka 1995, 33.

${ }^{15}$ Goran Davidović, Miloš Timotijević, Žena i rat. „Druga strana“ okupacije 19411944. godine na prostoru čačanskog kraja, Zbornik radova Narodnog muzeja, 33, Čačak, 147.

${ }^{16}$ Goran Davidović, Miloš Timotijević, Zatamnjena prošlost. Istorija ravnogoraca čačanskog kraja, I, Čačak 2002, 90.

${ }^{17}$ Vojni arhiv (VA), Na (Nemačka arhiva), 32-Ia-3 Saslušanje Pferer Tome, službenika Gestapoa u Beogradu.

${ }^{18}$ AS, BIA (Zbirka dokumenata Bezbednosno-informativne agencije), IV-50 Organizacija „Zbor" - zaplenjena dokumentacija.

${ }^{19}$ VA, Ča (Četnička arhiva), 20-1-35. 
Nemci pristojnije i uzdržanije odnose prema ženama u odnosu na bugarske vojnike koji su bili optuženi za mnogo veći broj izvršenih silovanja. ${ }^{20}$

Pošto je nemačka vojna komanda nastojala da obuzda seksualno nasilje od strane vojnika, podsticala je njihove kontakte sa prostitutkama, ali strogo vodeći računa o zaštiti od polnih bolesti. U tom smislu, područje Srbije je tretirano kao rizična oblast sa velikim brojem polno obolelih i bilo je podvrgnuto strogoj sanitarnoj kontroli. Štab Vojnog komandanta Srbije uputio je već 14. maja 1941. raspis lokalnim okupacionim organima u kome je isticana zabrana polnog snošaja sa srpskim ženama usled opasnosti od veneričnih bolesti, a posebno je upozoravano na žene koje se bave prostitucijom van javnih kuća. ${ }^{21}$

Opšta nemaština i moralno posrnuće koje je rat doneo uticali su na ogroman porast prostitucije tokom okupacije. Po nalogu okupatora, već početkom maja 1941. preduzete su u Beogradu mere za regulisanje prostitucije. ${ }^{22}$ Ubrzo potom, kolaboracionističke vlasti su usvojile Pravilnik o suzbijanju polnih bolesti i pronalaženju i nadzoru nad prostitucijom kojim su prostitutkama proglašene sve ženske osobe starije od 18 godina koje za novac ili neku drugu materijalnu dobit bludno žive. ${ }^{23}$ Prostitucija je legalizovana i zakonski kontrolisana, a praćeno je zdravstveno stanje prostitutki kao i vladanje osoba koje su bile sumnjive da nelegalno obavljaju slične poslove. Šef Upravnog štaba Harald Turner je u avgustu 1942. u izveštaju komandantu Jugoistoka isticao da je nadzor nad bludnicama neophodan $\mathrm{u}$ interesu održavanja zdravlja trupa. ${ }^{24}$

Prisustvo nemačkih vojnika u gradovima povećalo je potražnju za uslugama kafana i drugih lokala koji su držali prostitutke. ${ }^{25} \mathrm{U}$ većim centrima su ubrzo počele da se osnivaju i posebne javne kuće namenjene isključivo nemačkim vojnicima. U izveštaju dr Miloša Sekulića emigrantskoj vladi, pored isticanja brige nemačkih vlasti na predupređenju polnih bolesti,

20 Prema podacima Državne komisije za suđenje zločina okupatora i njegovih pomagača, u Srbiji je posle rata za period okupacije prijavljeno 3.639 slučajeva silovanja, od čega su u 772 slučaja počinioci bili Nemci, a u 1.834 Bugari. Arhiv Jugoslavije (AJ), 110 (Državna komisija za utvrđivanje zločina okupatora i njihovih pomagača) - 55 .

${ }^{21}$ VA, Na, 27I-1A-3.

22 Branislav Božović, Beograd pod komesarskom upravom 1941, Beograd 1998, $124-125$.

${ }^{23}$ Uslov za obavljanje prostitucije bio je telesno i duševno zdravlje, pre svega odsustvo polnih i drugih zaraznih bolesti. Sanitetska policija bila je zadužena za sanitetski nadzor nad prostitutkama u pogledu njihovih isprava, zdravlja i higijenskih uslova u stanovima. - Službene novine, 20. jun 1941, br. 82.

${ }^{24}$ Zbornik dokumenata i podataka o narodnooslobodilačkom ratu naroda Jugoslavije, I4, Borbe u Srbiji 1942. godine, Beograd 1954, 269.

${ }^{25}$ Miloš Timotijević, Prostitucija u Čačku tokom 20. veka, Tokovi istorije, 1-2/2007, 183. 
navedeno je i da je u Kosovskoj ulici u Beogradu otvorena javna kuća sa 300 žena i devojaka, namenjena isključivo nemačkim vojnicima i pod stalnom lekarskom kontrolom. ${ }^{26}$ Nasuprot ovoj preteranoj proceni, u decembru 1941. funkcionisala je javna kuća za nemačke vojnike u ulici Majke Jevrosime $\mathrm{u}$ kojoj se $\mathrm{u}$ tom periodu nalazilo 15 prostitutki. ${ }^{27}$ Bordel Vermahta otvoren je i u Požarevcu, gde je u jednom lokalu bilo odvojeno 7 prostitutki koje su bile pristupačne samo nemačkim vojnicima. ${ }^{28}$ Slična ustanova postojala je, po svemu sudeći, i u Valjevu. ${ }^{29}$

Još od ranije, beogradske prostitutke su preferirale rad u privatnoj režiji i kafanama, dok su izbegavale da rade po javnim kućama usled loših uslova i odnosa koji su u njima vladali. ${ }^{30}$ Prostitutke su često menjale mesta u kojima su radile, ali se menjao i sadržaj njihovih odnosa sa pojedinim okupatorskim vojnicima. Jedna od prostitutki koju je angažovao Vermaht u maju 1941, radila je u javnoj kući za nemačke vojnike do početka 1942. kada je odustala zbog prevelikog broja mušterija, što je bio razlog lične zabrinutosti za zdravlje. Nakon što je jedno vreme samostalno radila kao prostitutka, počela je da radi u javnoj kući u ulici Žorža Klemensoa. U toj javnoj kući je upoznala nemačkog vojnika koji se zaljubio u nju, iznajmio joj stan u Knez Mihailovoj ulici i izdržavao je, što je dovelo do ljubomorne scene kada ju je sreo na ulici sa nemačkim oficirom. Tom prilikom je klekao i molio ju je da mu se vrati. ${ }^{31}$

Prostitutke su po gradovima $u$ unutrašnjosti uglavnom radile $u$ kafanama i često su uživale zaštitu nemačkih vojnika kojima su pružale usluge. Usled toga bile su u značajnoj prednosti kada su dolazile u sukob sa okolinom. ${ }^{32}$ Dešavali su se i suprotni slučajevi kada je prevelika bliskost

${ }^{26}$ AJ, 103 (Emigrantska vlada Kraljevine Jugoslavije 1941-1945) -5-51.

${ }^{27}$ Prema izveštaju šefa Odseka za čuvanje morala Odeljenja socijalne politike i narodnog zdravlja Uprave grada Beograda za period od 14. do 21. decembra 1941. broj žena u javnoj kući u ulici Majke Jevrosime nije se povećao tokom decembra 1941. U periodu na koji se izveštaj odnosio u Beogradu su bile registrovane dve nove prostitutke, 11 osoba je upućeno na lečenje od polnih bolesti, a 42 ženske osobe otpuštene su iz bolnice kao izlečene. AS, G-10 (Ministarstvo rada, socijalnog staranja i narodnog zdravlja), 25567/41.

${ }^{28}$ Saša Marković, Stazama smelih. Monografija narodnooslobodilačkog rata na području opštine Požarevac, Požarevac 1979, 180. - Ova javna kuća nalazila se u hotelu „Srpski kralj“, a zatvorena je u julu 1943. - AS, BIA, I-7 Nemačka obaveštajna služba-Gestapo-Požarevac.

${ }^{29}$ Kafedžijka Sofija Rakić bila je posle rata optužena da je držala „javnu radnju samo za nemačke vojnike“. - Snežana Radić, Konfiskacija imovine u valjevskom okrugu 19441946, Valjevo 2002, 78.

${ }_{30}$ Vladimir Jovanović, Prostitucija u Beogradu tokom 19. veka, Godišnjak za društvenu istoriju, 1/1997, 15.

${ }^{31}$ Istorijski arhiv Beograda (IAB), Bds, S-230.

${ }^{32}$ Katica Knežević je proterana od strane gradske policije u Valjevu zbog širenja bluda među vojnicima i civilima, pre toga bila je već hapšena, ali su nemački vojnici uspevali 
pojedinih nemačkih vojnika sa ženama lakog morala izazivala negodovanje nemačke komande. ${ }^{33}$

Osim legalne prostitucije postojalo je više formi marginalnog ponašanja koje je obuhvatalo održavanje intimnih veza sa okupatorom. Na osnovu tih veza pojedine osobe dobijale su povlašćeno snabdevanje ili sticale druge vrste koristi, što se takođe može smatrati vrstom prostitucije. Neke od tih osoba su bile od ranije sklone nemoralnom ponašanju, pa su rat i prisustvo stranih vojnika pospešili kidanje obruča građanskih obzira i morala.

Ratne okolnosti, naročito odsustvo muškaraca koji su bili u oružanim odredima, zarobljeništvu ili su stradali, dovele su do toga da su se mnoge žene upuštale $u$ vanbračne ljubavne veze i postajale slobodnije $u$ polnom životu. ${ }^{34}$ Osetivši nadmoć nad okolinom stupanjem u veze sa nemačkim vojnicima, pojedine žene su se ponašale provokativno i arogantno. ${ }^{35}$ Mnoge su koristile kontakte sa nemačkim vojnicima da bi preko njih nabavljale namirnice. ${ }^{36}$ Predstavnici Nezavisne Države Hrvatske (NDH) u Beogradu pažljivo su pratili prelaske iz Beograda u Zemun, posebno tragajući za krijumčarskim i kurirskim kanalima. Jedan od načina da se dobije propusnica za ovaj prelazak bio je stupanje u odnose sa nemačkim vojnicima. ${ }^{37}$

Nemačke snage mogle su da ostvare direktniji i intimniji kontakt sa ženskim stanovništvom u gradovima, u čemu su ležali uzroci osude gradskih žena za nemoralno ponašanje. Do prisnijeg kontakta sa ženama iz grada dolazilo je useljavanjem nemačkih snaga u kuće u kojima im je dodeljivan prostor za stanovanje. U mnogim slučajevima zajednički stambeni prostor je predstavljao put zbližavanja srpskih žena i nemačkog okupatora. Mnoge ugledne žene iz građanskih porodica družile su se sa rukovodiocima okupacione službe, čak su i priređivale zabave kojima su oni prisustvovali, a ponekada bili i glavni gosti. ${ }^{38}$ Okupacioni vojnici i njihove pratilje nisu se

da je zadrže u Valjevu. IAB (Istorijski arhiv Beograda), UgB-SP (Uprava grada Beograda Specijalna policija) III-21/20, k. 149/16.

${ }^{33}$ Takav slučaj desio se sa prostitutkom koja je u radila u kafani u Lapovu koja je bila poreklom sa teritorije NDH i koja je proterana na zavičajnu teritoriju. - IAB, UgB-SP III-21/23, k. 149/20.

${ }_{35}^{34}$ G. Davidović, M. Timotijević, Zatamnjena prošlost..., III, 242.

35 Jedna Beograđanka je sablažnjavala komšiluk ispraćajući nemačke vojnike i „pojavljujući se izvan stana u prozirnoj spavaćici“. - AS, G-25 (Zemaljska komisija za utvrđivanje zločina okupatora i njegovih pomagača), f. 9, Zl. br. 1745.

${ }^{36}$ AS, G-25, f. 9, Zl. br. 1772.

${ }^{37}$ Aleksandar Vojinović, NDH u Beogradu, Zagreb 1995, 148.

${ }^{38}$ AJ, 110, inv. br. 4252. Zapisnik saslušanja Gušić Ivana, tumača agenta krajskomandanture u Kragujevcu. - Postoje svedočenja i da je komandant SS-a i policije August Majsner u Beogradu imao za ljubavnice dve sestre iz ugledne beogradske porodice koje su zbog toga posle oslobođenja streljane. - Mi smo preživeli... Jevreji o holokaustu, II, Beograd 2003, 324 . 
ustručavali od pojavljivanja $u$ javnosti i učešća $u$ društvenom životu, a $u$ tom smislu doživljavani su kao buduća elita. ${ }^{39}$

Okupacija je donela i osećaj da su nestale ranije norme ponašanja i vladanja, pa su pojedine žene stupale u intimne veze sa okupatorskim vojnicima naočigled supruga i ostalih ukućana. ${ }^{40}$ Ponekad je stupanje u ljubavnu vezu sa predstavnicima okupatorskih vlasti vršeno uz prećutnu saglasnost i odobravanje članova porodice, čak i na njihov podsticaj. Često su muževi tolerisali ovakvo ponašanje, a neki su ga i podsticali pošto su na taj način sticali zaštitu okupatora i mogli da se slobodno bave švercom i crnom berzom. ${ }^{41}$

Dok su se posle rata mnogobrojne prijave odnosile na žene koje su priređivale terevenke i igranke sa nemačkim vojnicima, postoje prijave i protiv onih koje su viđane isključivo u društvu jednog nemačkog vojnika sa kojima su se pojavljivale i u javnosti. ${ }^{42}$ Diskretne ljubavne veze bile su evidentirane i praćene i od strane okupatora, naročito ukoliko je postojala sumnja u političku pouzdanost partnera. ${ }^{43}$

Intimne veze najlakše su uspostavljane sa osobama koje su se nalazile u neposrednoj blizini okupacionih predstavnika, pre svega sa ženama koje su angažovane kao pomoćno osoblje okupacionih snaga. U nemačkoj službi našao se veliki broj žena koje su za potrebe okupatora obavljale poslove prevodilaca, sekretarica, daktilografkinja, kuvarica i čistačica. Žene koje su radile za okupatorske snage često su im i ideološki bile bliske, a mnoge od njih su stupale u ljubavne odnose sa nemačkim vojnicima. To je ponekad bilo i pitanje hijerarhije, pa su žene koje su zauzimale istaknutije položaje stupale u veze sa predstavnicima okupacionih vlasti višeg ranga. ${ }^{44}$

${ }^{39}$ Milan Jovanović Stoimirović je u svom dnevniku u novembru 1942. ostavio belešku o poseti jednoj pozorišnoj predstavi kojoj su takođe prisustvovali nemački i italijanski vojnici, za koje je pretpostavljao da ne mogu razumeti predstavu, ali su sa svojim pratiljama predstavljali atrakciju za ostale posetioce kojima je bilo „kolosalno zanimljivo razgledati tu gomilu koja dolazi, taj novi, budući svet“. Milan Jovanović-Stoimirović, Dnevnik, rukopis, Matica srpska.

${ }^{40}$ G. Davidović, M. Timotijević, Zatamnjena prošlost..., III, 240-241.

${ }^{41}$ AS, BIA, IV-50 Organizacija "Zbor" - zaplenjena dokumentacija.

${ }^{42}$ AS, G-25, f. 15, Zl. br. 2392.

${ }^{43}$ Devojka sumnjiva zbog davanja privatnih časova engleskog jezika, u aprilu 1943. bila je evidentirana od strane Specijalne policije uz napomenu da ima verenika nemačkog podoficira koji kod nje dolazi svako veče. - IAB, UgB-SP III-6/17, k. 143/15.

${ }^{44}$ Milena Spasić, tumač feldkomandanture u Užicu i Šapcu, a zatim tumač Gestapoa, bila je u ljubavnoj vezi sa Paulom Vilijamom, šefom Gestapoa u Šapcu „kome se u duševnom i telesnom pogledu svestrano podala, pa je čak sa njim putovala za Nemačku i tamo ostala provodeći u Ulmu oko dva meseca u toku leta 1942". - AS, G-25, f. 9, Zl. br. 1755. - O ponašanju Spasićeve prikupljao je podatke ravnogorski pokret, jer su njena dva brata bili generalštabni oficiri, ratni zarobljenici u Nirnbergu. Posle oslobođenja Spasićeva se povukla sa nemačkom vojskom, a njen predmet je iz Suda za suđenje zločina i prestupa 
Posle zaposlenja kod nemačkih okupacionih službi mnoge žene koje ranije nisu bile politički opredeljene počele su da promovišu interese okupatora i sa njima provode slobodno vreme. ${ }^{45}$

Žene koje su vrbovane u službu okupatora kao obaveštajni agenti u velikom broju slučajeva bile su u ljubavnim vezama sa pretpostavljenim nemačkim službenicima, a računalo se na njihove seksualne usluge prilikom pribavljanja informacija. Značajnu obaveštajnu ulogu imala je Desanka Pajčić Ciga koja je bila je blizak saradnik nemačkog obaveštajca Sesila Nasenštajna kome je bila ljubavnica, kao i obaveštajcu koji je nasledio Nasenštajnov položaj i rad sa njom kao agentom. ${ }^{46}$ Obaveštajka Marion Bruderer je u cilju prikupljanja obaveštajnih podataka koristila seksualne usluge. ${ }^{47}$ Njen sekretar Ivo Volek je sumnjičen da mu je glavno zaposlenje vrbovanje mladih i lepih srpskih devojaka i žena „nemačkim oficirima za razonodu". ${ }^{48}$

Među ženama koje su bile saradnice nemačke obaveštajne službe najintrigantniji je slučaj Vere Pešić, koja je još u međuratnom periodu bila u ljubavnoj vezi sa SS majorom Karlom Krausom, a smatra se da je bila i ljubavnica generala Badera, vojnog zapovednika Srbije. ${ }^{49}$

Javnost je pratila i oštro osuđivala veze žena sa okupatorom, očekujući njihovo kažnjavanje po završetku rata. I tokom rata žene su upozoravane na takvo ponašanje. Pripadnici Jugoslovenske ravnogorske omladine $u$ užičkom kraju izveštavali su u januaru 1943. da su sastavili spisak žena koje su u intimnim vezama sa nemačkim okupatorom i da je reč o 33 osobe, uglavnom omladinke. Tim povodom su izradili letak u kome su naveli imena optuženih žena i podmetali ga građanstvu, što je prema njihovim tvrdnjama imalo dejstva na držanje pojedinih osoba navedenih u spisku. ${ }^{50}$

Javno isticanje imena žena koje su se vezama sa okupatorom ogrešile o nacionalnu čast primenjivano je i u Kraljevu od strane ravnogoraca. Za ovo mesto navedeno je preko 40 žena koje su u ljubavnim vezama sa

protiv srpske nacionalne časti u Užicu prebačen u nadležnost vojnog sudstva zajedno sa više izjava da nije učestvovala u denuncijacijama.

${ }^{45}$ Dve žene koje su u Topoli bile zaposlene kao kuvarice za nemačke snage, pre rata bile su politički neaktivne, da bi posle zaposlenja počele da propagiraju nacističku ratnu nepobedivost i javno se viđaju i žive sa nemačkim vojnicima. - AS, BIA, I-7 Nemačka obaveštajna služba-Gestapo-Požarevac.

${ }^{46}$ Nemačka obaveštajna služba, IV, Beograd 1959, 211.

${ }^{47}$ Brudererova je opisana kao u „seksualnom pogledu vrlo agresivna“ osoba koja je sa više agenata, mahom mladih ljudi, imala intimne odnose. - Nemačka obaveštajna služba..., 289.

${ }^{48}$ Simo C. Ćirković, Ko je ko u Nedićevoj Srbiji 1941-1944. Leksikon ličnosti. Slika jedne zabranjene epohe, Beograd 2009, 47.

${ }^{49}$ Venceslav Glišić, Dosije o Veri Pešić ili kako ne treba pisati istoriju obaveštajca, Vojnoistorijski glasnik, 2/2009, 178.

${ }^{50}$ VA, Ča, 130-1-12. 
nemačkim, bugarskim i albanskim snagama, ali i ljotićevcima. Karakteristično je da su žene na spisku grupisane, pa su zajedno navođene majke i kćeri, sestre, drugarice ili stanodavka i podstanarka koje su zajedno sprovodile nemoral. One su optuživane da prave sedeljke i igranke sa „najvećim neprijateljima Srpstva" i da ih čekaju vešala koja su i slikovno predstavljena na proglasu. ${ }^{51}$

Od strane ravnogorskog pokreta izdato je nekoliko proglasa kojima se nastojala skrenuti pažnja na nemoralno ponašanje pojedinih žena i uticati na promenu njihovog držanja. U proglasima su osuđivane žene koje „podaju poštenje ubicama braće svoje“, kao i slučajevi nemoralnog ponašanja udovica, koje „posle bludne noći, provedene sa ubicama, dođu na groblje i tu pred svetom reklamiraju svoju veliku žalost". Posebno je osuđivan pad morala kod ženskog sveta u gradovima, naročito kod obrazovanih žena, uz konstataciju da takvo ponašanje predstavlja zločin prema naciji pošto se nametalo pitanje kako će takve nemoralne osobe kasnije vaspitavati decu u nacionalnom duhu. Za moralno posrnuće su optuživani i roditelji koji nisu posvećivali pažnju vaspitanju dece, naročito kontroli ponašanja kćeri. ${ }^{52}$ Završni deo većine proglasa imao je preteći karakter, ukazivano je na nejasnu kaznu „žigom sramote“ i savetovano ostalim ženama da se klone onih koje se nemoralno vladaju. ${ }^{53}$

Žene koje su bile bliske okupatoru u Francuskoj su izložene napadima još od rane 1943. godine. Mnogi Francuzi su smatrali da su žene koje su bile u vezama sa Nemcima sklone denuncijaciji svojih sunarodnika nemačkim vlastima, a neprijateljstvo prema ženama pojačalo se po povratku ratnih zarobljenika među kojima su mnogi smatrali da su ih žene izdale. Uobičajena kazna za žene optužene za kolaboraciju koja je sprovođena vansudskim putem bila je brijanje glave. Ovu kaznu je posle oslobođenja ponekad pratila i neka druga vrsta nasilja - žene su razodevane, gonjene ulicama, neke su i silovane. Iako je manje od polovine žena kojima su u Francuskoj obrijane glave bilo optuženo za stupanje $u$ intimne veze sa okupatorom, ova optužba uglavnom se smatra glavnom krivicom žena tokom okupacije. ${ }^{54}$ Činjenica da su bez kose ostale i žene koje su bile kažnjavane za druge vidove kolaboracije govori u prilog tome koliko su pol i seksualnost uslovljavali pojam izdaje uopšte, a žene koje su imale veze sa nemačkim vojnicima

\footnotetext{
${ }^{51} \mathrm{VA}, \mathrm{Ča}, 255-1-52$.

${ }^{52}$ VA, Ča, 240-7-26. „Roditeljima naših devojaka (na razmišljanje)“

${ }^{53}$ VA, Ča, 255-1-54.
}

${ }^{54}$ Između juna 1943. i marta 1946. u Francuskoj je 20.000 žena obrijano do glave na osnovu optužbe za kolaboraciju sa nemačkim okupatorima, od čega se $40 \%$ slučajeva odnosilo na optužbe za prostituciju ili seksualno opštenje sa neprijateljem. - Vofgang Šmale, Istorija muškosti u Evropi 1450-2000, Beograd 2011, 251. 
odmah dovođene u vezu sa seksualnom nemoralnošću. One koje su imale seksualne veze sa okupatorom, automatski su smatrane promiskuitetnim i na taj način su kažnjavane ne samo za ponašanje protivno nacionalnim interesima već i za kršenje javnih normi ponašanja. ${ }^{55}$

Tokom prve polovine 20. veka brijanje glave ženama pojavljivalo se u praksi mnogih evropskih zemalja. Prvi slučajevi zabeleženi su u Belgiji krajem Prvog svetskog rata zbog saradnje sa okupacionim snagama. ${ }^{56} \mathrm{U}$ međuratnom periodu u Rajnskoj oblasti i Nemačkoj brijanje glave ženama bilo je rasistički motivisano i upereno protiv žena koje su bile protivnice nacista, koje su bile Jevrejke ili u intimnim vezama sa Jevrejima. ${ }^{57} \mathrm{U}$ Španiji i kasnije u Grčkoj u periodu građanskog rata brijanju glava bile su izložene žene koje su podržavale snage levice. Krajem Drugog svetskog rata brijanju glava zbog bliskih veza sa okupatorom bile su izložene žene u Francuskoj, Belgiji, Danskoj, Holandiji, Norveškoj. ${ }^{58}$ O efektu koji je u javnosti ostavilo brijanje glava govori i pojava niza književnih dela koji se bave tom temom, od stvaralaštva Margaret Diras (Hirošimo, ljubavi moja) do Justejn Gorder. ${ }^{59}$

Brijanje glave vršeno je isključivo od strane muškarca, što se može smatrati simboličkim činom ponovnog uspostavljanja patriotske muškosti, afirmacijom muške dominacije i „skidanja ljage“ sa nacije, koja joj je naneta putem seksualnog opštenja sa neprijateljem. ${ }^{60}$ Brijanje glave je $\mathrm{u}$ tom smislu predstavljalo čin pročišćenja. Činjenica da su muškarci držali makaze imala je simboličke seksističke oznake. Gubitkom kose žene su gubile zna-

${ }^{55}$ Surviving Hitler and Mussolini..., 121.

${ }^{56}$ F. Virgili, n.d., 213.

57 „Arijevske" žene koje su se zaista ili navodno upustile u vezu sa nekim Jevrejinom bile bi ošišane i vučene kroz grad“. - Gizela Bok, Žena u istoriji Evrope. Od srednjeg veka do danas, Beograd 2005, 336.

${ }^{58}$ Tokom Drugog svetskog rata nekoliko desetina hiljada Dankinja bilo je u vezama sa vojnicima Vermahta iz kojih je rođeno više od 5.500 dece. Obim ovih veza u zemlji sa manje od 4 miliona stanovnika uticao je da žene postanu mete pokreta otpora. Prvi slučaj šišanja kose dogodio se u Danskoj 1940. godine, a od 1943. broj slučajeva raste. - Lulu Anne Hansen, 'Youth Off the Rails': Teenage Girls and German Soldiers - A Case Study in Occupied Denmark, 1940-1945, Brutality and Desire. War and Sexuality in Europe`s Twentieth Century, Edited by Dagmar Herzog, Palgrave Macmillan, New York, 2009, 139. - Slučajeva brijanja glava ženama bilo je i u Italiji zbog saradnje sa nemačkim okupatorom posle kapitulacije, dok se na britanskom ostrvu Džersi sa preuveličavanjem govorilo o 3.000 dece rođene iz ovakvih veza. Posle oslobođenja britanski vojnici su više puta intervenisali da spreče brijanje glava ženama od strane lokalnog stanovništva. (F. Virgili, $n$. d., 214).

${ }_{59}$ Justejn Gorder opisuje šišanje žene koja je imala dete iz ljubavne veze sa nemačkim vojnikom u Norveškoj, kao i teškoće posleratnog života osoba koje su nosile žig „horizontalne kolaboracije" i koje su uglavnom bile prisiljene da napuste sredinu i preseljenjem oslobode svoj život tereta rata. - Justejn Gorder, Misterije pasijansa, Beograd 2002, 21-22.

${ }^{60}$ V. Šmale, n. d., 252. 
čajnu odliku ženstvenosti, a kazna je imala za cilj deseksualizaciju, simboličku žensku kastraciju i istovremeno predstavljala demonstraciju muške dominacije. ${ }^{61}$ Brijanje glava ženama imalo je simboličko značenje i usled činjenice da je moglo predstavljati i odgovor na emancipaciju žena u međuratnom periodu kada je bila prihvaćena moda ženske frizure sa kraćom kosom. ${ }^{62}$

Prisilno šišanje žena kao kazna zbog saradnje sa okupatorom ili stupanja sa njim $u$ intimne odnose postojalo je u Srbiji tokom Prvog svetskog rata. ${ }^{63}$ U Prokuplju je po naređenju četovođe Mašana Stojovića ošišano nekoliko žena i devojaka za koje se znalo da su saradnice ili ljubavnice bugarskih starešina i vojnika. ${ }^{64}$

Kažnjavanje žena šišanjem primenjivao je ravnogorski pokret $u$ Srbiji još na početku okupacije u slučajevima žena i devojaka koje su imale bilo kakve veze sa okupatorskim vojnicima. Prema tvrđenju majora Velimira Piletića, komandanta ravnogorskog Krajinskog korpusa, u podunavskoj oblasti bile su ošišane dve mlade žene, što je imalo velikog efekta, pa su žene izbegavale i slučajne susrete sa okupatorskim vojnicima. ${ }^{65} \mathrm{U}$ kraju pod Piletićevom komandom šišanje i udaranje batina bilo je primenjeno i u slučaju dve seljanke koje su izvršile pobačaj koji se završio sa smrtnim ishodom. ${ }^{66}$

Najveći broj prisilnih šišanja žena u okupiranoj Srbiji izvršen je tokom 1943. i 1944. godine, odnosno približavanjem kraja okupacije. Iako je čin šišanja najčešće primenjivan kao kazna za žene koje su stupale u ljubavne veze sa okupatorom, $u$ više slučajeva postojali su drugačiji razlozi za ovaj vid kažnjavanja. Šišanje je kao kazna primenjivano u januaru 1943. u slučajevima žena čiji su muževi pobegli iz četničkih redova. ${ }^{67}$ Teži prestupi od strane žena kažnjavani su, uz šišanje, i dodatnim javnim udaranjem batina, ali su motivi ovih kažnjavanja često ostajali nerazjašnjeni i nejasni. ${ }^{68} \mathrm{U}$ nekoliko slučajeva zabeleženo je šišanje i udaranje batina ženama kao

${ }^{61}$ Surviving Hitler and Mussolini..., 120.

${ }^{62}$ F. Virgili, n. d., 181.

${ }^{63}$ U domaćim izvorima upotrebljava se uglavnom izraz šišanje, dok se ređe spominje brijanje glava za razliku od slučajeva u Zapadnoj Evropi gde u upotrebi preovlađuje drugi termin. U francuskom jeziku u upotrebi je specifičan izraz tonte koji se isključivo koristi za fenomen prisilnog brijanja glava ženama. - F. Virgili, $n$. $d ., 1$.

${ }^{64}$ Teža kazna zadesila je suprugu samog Mašana Stojovića koja je saradnju sa Bugarima platila glavom. - Božica Mladenović, Žena u Topličkom ustanku 1917, Beograd 1996, 78.

${ }^{65}$ Velimir Piletić, Sudbina srpskog oficira, Kragujevac 2002, 66.

${ }^{66}$ Isto.

${ }^{67}$ Takvi slučajevi zabeleženi su u Trnavi. - AS, Đ-2 (Centralni komitet Saveza komunista Srbije), OK Ar, 59.

${ }^{68}$ Božidarka Damnjanović Kika je u julu 1943. javila da su četnici u Zaklopači zaklali jednu ženu iz Boleča, a drugu prebili i ošišali. - AS, Đ-2, OKM, 292. 
posledica njihove pripadnosti ili pripadnosti najbližih srodnika narodnooslobodilačkom pokretu. ${ }^{69}$

Često nerazjašnjeni motivi šišanja upućivali su na seksualno ucenjivanje od strane pripadnika ravnogorskog pokreta. Tokom maja 1944. iz Svilajnca su pristizale žalbe na ljudstvo ravnogorskog Resavskog korpusa koje je ošišalo mnoge devojke i žene zato što nisu pristajale na ljubavne odnose sa članovima pokreta, ali je verodostojnost ovih tvrdnji bila upitna pošto je dolazila od jedne od ošišanih žena, $\mathrm{i}$ to supruge ratnog zarobljenika. ${ }^{70}$ Međutim, i za Drugu trsteničku brigadu upućivane su žalbe da četnici nasrću na žene i da one koje odbijaju njihove ljubavne ponude dobijaju batine i pretnje da će biti obeležene kao saradnice okupatora. ${ }^{71}$

Šišanje žena primenjivano je i u Četvrtoj trsteničkoj brigadi gde je, kao i u slučaju sela Drževca, predlagano od strane sveštenika koji su sarađivali sa ravnogorskim pokretom. ${ }^{72}$ U Bogovađi je i fotografisano šišanje jedne devojke. Iz Svilajnca su u novembru 1943. odvedene tri žene i „sve tri ošišane mašinom a zatim puštene na slobodu i rečeno im je da se više ne vucaraju sa okupatorom “.$^{73}$ Šišanja i batinjanja žena su vršena u valjevskom kraju od strane pripadnika Kalabićeve Gorske garde, kada je dospela na taj teren u junu 1943. ${ }^{74}$ Čak su se i predstavnici Valjevske brigade žalili na ovakve postupke Gorske garde, što ukazuje na njihovu proizvoljnost i nasilnost. ${ }^{75}$ Posle oslobođenja razbijene četničke snage su vršile napade na partizanske porodice, a u slučajevima žena primenjivali i šišanje. ${ }^{76}$

Posle rata, prilikom prijavljivanja zločina, sačuvan je mali broj prijava ošišanih žena upravo zbog toga što je vladalo mišljenje da su na taj način kažnjavane za nemoral ili saradnju sa okupatorom. U pojedinim slučajevima gde su prijavljivani ovakvi postupci često se u dokumentaciji nalaze dopisani uzdržani stavovi, preispitivanje razloga ili drugi znaci koji ukazuju na sumnju prema podnosiocima prijava. ${ }^{77}$ Usled takvog tretmana mali je

${ }^{69}$ Jedna žena iz Velike Plane ošišana je jula 1944. zbog braće koji su bili u partizanskim redovima, dok je druga iz Sijerinske Banje tučena i silovana zbog muža partizana. - AS, AFŽ (Antifašistički front žena Srbije - Glavni odbor), svežanj. AS, G-25, f. 39, Zl. br. 5361.

${ }^{70}$ VA, Ča, 87-2-12.

${ }^{71} \mathrm{VA}, \mathrm{Ča}, 80-2-45$.

${ }^{72}$ AJ, 110-40-107.

${ }^{73}$ Izveštaji Komande srpske države straže za okrug moravski 1941-1944. Priredili: Dobrivoje Jovanović, Dejan Tanić, Jagodina 2001, 115.

${ }_{74}$ Bojan Dimitrijević, Valjevski ravnogorci - Jugoslovenska vojska u otadžbini u valjevskom kraju 1941- 1945, Valjevo 1998, 197.

${ }^{75}$ Kosta Nikolić, Istorija ravnogorskog pokreta 1941-1945, I, Beograd 1999, 310.

${ }^{76}$ Goran Davidović, Miloš Timotijević, Dan posle - uništavanje organizacije JVuO i uspostavljanje vlasti komunista u čačanskom kraju 1944-1945, Istorija 20. veka, 2/2004, 34.

77 Zabeležen je slučaj domaćice koju su avgusta 1944. istukli četnici ispred kafane u Stepojevcu, a mesec dana kasnije ošišali je na javnom mestu i naredili da prođe kroz selo 
broj prijavljenih slučajeva šišanja u posleratnim istragama. U evidenciji Državne komisije za utvrđivanje zločina okupatora i njegovih pomagača postoje prijave samo za Posavski okrug i to za teritoriju Umke gde je prijavljeno 12 slučajeva šišanja. ${ }^{78}$ Ova pojava je ubrzo našla svoje mesto i u posleratnoj literaturi. ${ }^{79}$

Švedski novinar koji je u aprilu 1944. objavio reportažu o životu u Beogradu, konstatovao je da „šumski ljudi Draže Mihailovića brijaju glave srpskim devojkama koje se druže sa Nemcima, a Titovi partizani postupaju sa njima još gore". ${ }^{80}$ Posle rata mnoge žene bile su osuđene na zatvorske kazne i gubitak nacionalne časti zbog održavanja intimnih veza sa okupatorskim vojnicima. Naročito one žene koje su bile optužene za privrednu saradnju sa okupatorom, bile optuživane i za održavanje intimnih odnosa sa njima. ${ }^{81}$ Presudnu ulogu mogli su imati komplikovani privatni i lični odnosi naročito $u$ pogledu braka i intimnog života. ${ }^{82} \mathrm{U}$ mnogim slučajevima odlučujuću ulogu imala je lična procena odabranih svedoka, ali i čaršijske priče i ogovaranja kojima su pojedine žene etiketirane na osnovu malograđanskih kriterijuma. Nemoralnost žena viđena $u$ činu stupanja u intimne odnose sa okupatorom bila je tretirana kao čin nacionalne neispravnosti. Žene koje su bile na glasu kao „ljubavnice nemačkih oficira“ olako su posle oslobođenja postale žrtve posleratne represije i zbog moralnih sagrešenja izgubile i živote. ${ }^{83}$ Nasuprot tome, muškarci koju su u zarobljeništvu ili na

držeći u ruci ošišanu kosu. Pored konstatacije da je zlostavljana zato što joj je muž streljan, ostala je zabeleška da stvarni motiv zločina nije utvrđen. - AS, AFŽ.

${ }^{78}$ Prijavljeni su slučajevi u selima: Dražnjevac, Konatica, Mala Moštanica, Mislođin, Ponjane i Rucka. - AJ, 110-55-27.

${ }^{79}$ Čin šišanja žena koje su stupale u ljubavne veze sa okupatorom od strane četnika spominje se u drami Dragoslava Mihailovića „Kad su cvetale tikve“, što je u to vreme moglo biti smatrano subverzivnom tvrdnjom, jer „ako četnici, smatrani za kolaboracioniste, napadaju žene koje spavaju sa okupatorom, onda to liči na slične akcije, na primer, francuskog pokreta otpora“. - Aleksandar Novaković, Kako je Tito razbijao „Tikve“. Istorija zabrane pozorišne predstave "Kad su cvetale tikve“ Dragoslava Mihailovića (JDP 25. 10. 1969), Beograd 2005, 22.

${ }^{80}$ AJ, 103-167-183.

${ }^{81}$ Momčilo Mitrović, Srpska nacionalna čast pred zakonom 1945. godine, Beograd $2007,326$.

${ }^{82}$ Kao primer može poslužiti slučaj Branke Kudre iz Beograda koja je osuđena na godinu dana gubitka nacionalne časti jer je po izjavi muža i jedne svedokinje za vreme okupacije u radnji muža i u njegovom odsustvu sedela sa nemačkim vojnikom i pila liker, a drugi put sa nemačkim tenkistom šetala „ispod ruke“ avalskim putem. Optužena je negirala navode tvrdeći da joj je suđenje namestio muž koji je i sam rekao kako prateći ženu nije stekao utisak da je održavala bliže lične odnose sa nemačkim vojnicima, dok je više svedoka izjavilo da je reč o poštenoj i vrednoj ženi. - Momčilo Mitrović, Srpska nacionalna čast..., 92.

${ }^{83}$ U Požarevcu su kao ljubavnice nemačkih oficira streljane dve žene. - Srđan Cvetković, Između srpa i čekića. Represija u Srbiji 1944- 1953, Beograd 2006, 212. 
prinudnom radu uspostavili seksualne veze sa Nemicama nisu bili tretirani kao prekršioci ni nacionalnih ni moralnih normi. ${ }^{84}$

Prema proceni dr Momčila Mitrovića, na svakih 100 muškaraca optuženih pred Komisijom za ratne zločine dolazila je jedna žena, dok su najčešće optužbe protiv žena sadržavale kvalifikacije kao što su denuncijacija, potkazivanje, maltretiranje ranjenika, iživljavanje na leševima, mučenja i zlostavljanja zarobljenika, izdaja naroda, slanje u logor, batinjanja. ${ }^{85}$ Kažnjavanje žena pred sudovima nacionalne časti bilo je češće nego pred vojnim sudovima, a mnoge optuženice su odgovarale o pitanjima intimnog života. Broj optuženih žena znatno je proširen i time što su se pred sudom našle i žene koje su održavale intimne odnose sa pripadnicima kolaboracionističkih ili ravnogorskih snaga. Sud za suđenje zločina i prestupa protiv srpske nacionalne časti u Čačku osudio je u celom okrugu 39 lica od kojih je bilo 17 žena. Od ovog broja, sedam žena je osuđeno zbog kvalifikacija koje su se, između ostalog, odnosile i na prijateljske odnose sa pripadnicima okupatorske vojske i vlasti. Među optuženima od suda časti u Čačku našla se i bivša učenica gimnazije koja je osuđena na godinu dana lakog prinudnog rada i dve godine gubitka građanske časti jer je za vreme okupacije održavala prisne prijateljske odnose sa pripadnicima okupatorske vojske. Krivica se sastojala u tome što je viđena $u$ dva maha na plaži u Čačku u kupaćem kostimu sa jednim nemačkim oficirom sa kojim je u vrbaku kraj Morave ostala nekoliko časova, kao i zbog toga što je održavala prijateljske odnose sa takozvanim domaćim izdajnicima. ${ }^{86}$

Ženama optuženim za nemoralno držanje pod okupacijom često je posle rata bilo organizovano grupno suđenje. ${ }^{87}$ Kao primer grupnog suđenja ženama optuženim za održavanje intimnih i prijateljskih veza sa okupatorom može poslužiti suđenje održano pred Sudom za suđenje zločina i prestupa protiv srpske nacionalne časti u Užicu. Dok je ravnogorski proglas za intimne veze sa okupatorom optuživao 33 užičke omladinke, u procesu koji su vodile komunističke vlasti osuđeno je devet žena mahom iz uglednih građanskih porodica, dok su dve bile oslobođene optužbi. ${ }^{88}$ Sve osuđene

${ }^{84}$ Pojedini su se, kao u Nišu, vratili u zemlju sa suprugama Nemicama. - AS, BIA, IV-12, Nemačka policija u Nišu.

${ }^{85}$ Momčilo Mitrović, Žene i represivno zakonodavstvo u Srbiji 1944-1952, Srbija u modernizacijskim procesima 19. i 20. veka, II, Položaj žene kao merilo modernizacije, naučni skup, Beograd 1998, 42. - Radi poređenja broja optuženih žena može se navesti slučaj Češke čiji su sudovi koji su od juna 1945. do maja 1947. sudili optuženima za saradnju sa okupatorom imali 33.000 optuženih, od kojih je svaki šesti bila žena, među kojima je skoro podjednak bio broj Čehinja i Nemica. - B. Frommer, $n$. d., 112.

${ }^{86}$ G. Davidović, M. Timotijević, Dan posle..., 43.

${ }^{87}$ U Nišu je suđeno grupi od šest žena, „većinom udatih“. - Nataša Milićević, Jugoslovenska vlast i srpsko građanstvo 1944-1950, Beograd 2009, 337.

${ }^{88}$ M. Mitrović, Srpska nacionalna čast ..., 59-72. 
proglašene su 25. juna 1945. između ostalog krivima po zajedničkoj tački optužbe da su „za vreme okupacije održavale prisne i prijateljske odnose sa pripadnicima okupatorske vojske i vlasti time što su vrlo često bile u društvu nemačkih oficira i vojnika, nemačkih oficira policije Gestapoa, kao i u društvu domaćih izdajnika četničkih i Nedićevih oficira i što su sa ovim zlotvorima održavale prisne odnose“. Za pet osuđenih ovo je bila jedina stavka optužbe, jedna od žena bila je osuđena i za ekonomsku saradnju, jedna za denuncijacije, a dve za propagandu protiv narodnooslobodilačkog pokreta i u korist okupatora. Otežavajuća okolnost za pet osuđenih žena bila je činjenica da su im se muževi tokom okupacije nalazili u zarobljeništvu. Pored tri žene koje su osuđene u odsustvu, najteža presuda bila je kazna od 10 godina gubitka nacionalne časti i 3 godine teškog prinudnog rada. Međutim, ženi osuđenoj na tu kaznu već u avgustu je kazna smanjena na 2 godine prinudnog rada. Prilikom obnove postupka u oktobru 1945. ona je osuđena na 3 godine gubitka nacionalne časti i 4 meseca prinudnog rada. Prvobitna presuda bila je osporena nakon što je iskaz glavnog svedoka doveden u pitanje, pošto je po svemu sudeći bila reč o osveti odbijenog muškarca. ${ }^{89}$ Da je ovaj proces imao i karakteristike obračuna sa političkim protivnicima, govori i činjenica da se među optuženima našla Nada Mirković Lautner, supruga komandanta 10. dobrovoljačkog odreda Miloša Vojinovića Lautnera i ćerka trgovca i predsednika opštine Andrije Mirkovića, koga su aprila 1945. streljale nove vlasti. Osuđene su i dve ćerke političara Čedomira Zaharića, dok je treća oslobođena optužbi.

Premda je teško izvršiti kvantifikaciju, „horizontalna kolaboracija“ u Srbiji, uslovljena težim režimom okupacije, nije imala razmere sličnih pojava u porobljenim zemljama Zapadne Evrope, ali nije bila ni zanemarljiva. Nije bio zanemarljiv ni uticaj koji je takvo ponašanje ostavljalo na javno mnjenje koje je budno pratilo vladanje žena. Patrijarhalna moralna pravila su sa posebnom strogošću regulisala ponašanje, ljubavni i seksualni život žena. Okupacija i propast države, kao i poraz muškaraca u ratu uticali su na slabljenje patrijarhalnog poretka koji je ulogu žene u ratu video kao svetu dužnost. Od žena je očekivano da budu majke i brinu o domaćinstvu, a umesto toga one su odsutne i poražene muškarce zamenile okupatorom. Seksualnim vezama sa okupatorom žene su ugrozile nacionalno i muško vlasništvo nad ženskom seksualnošću. Žene koje nisu ispunile očekivanja nisu bile dorasle idealu koji su tradicija i društvo postavili u poštovanju seksualnosti i tretirane su kao pretnja za opstanak nacije.

O značaju koji je pridavan „horizontalnoj kolaboraciji“ svedoči i to da je kažnjavanje žena za intimne veze sa nemačkim okupatorom vršeno i

${ }^{89}$ Istorijski arhiv Užice, Okružni sud u Užicu, KNO i konf. Ča/a 1945, fasc. Nacionalna čast. 
od strane ravnogorskog i narodnooslobodilačkog pokreta. Dok je ravnogorski pokret u slučajevima takvih žena pribegavao prisilnom šišanju, narodnooslobodilački pokret ih je posle oslobođenja sankcionisao sudskim putem. Od strane oba pokreta među optuženim za „horizontalnu kolaboraciju“ našle su se i žene koje su smatrane ideološkim protivnicama. U kažnjavanju koje su primenjivala oba pokreta, seksualne optužbe su često prikrivale ideološko razmimoilaženje koje je prebacivano na polje seksualnosti. Skrivanje ideologije iza optužbi za seksualne prekršaje predstavljalo je pokušaj da se žene degradiraju u okvirima roda i da im se na taj način uskrati pravo na ravnopravnost i emancipaciju. 
Ljubinka Škodrić

'THE HORIZONTAL COLLABORATION' - INTIMATE RELATIONSHIPS BETWEEN WOMEN AND GERMAN FORCES IN OCCUPIED SERBIA 1941-1944

\section{Summary}

Intimate fraternization with occupying forces was typical phenomenon for all territories under German occupation during World War II. Although it depended on the regime of occupation, number of the occupying forces and general sympathies towards Nazism, it became the most detested form of collaboration. Women fraternization with Germans was condemned since it was considered betrayal of national and patriarchal norms and morals. Cutting of women's hair became a method of punishing women for intimate relations with German soldiers by Ravna Gora Movement during the occupation. On the other hand, after liberation, People's Liberation Movement organized trails for women charged for 'horizontal collaboration'. Punishment by cutting hair as well as post-war trails, beside real charges for sexual relationships had, in numerous cases, background in ideological disapproval. Concealing ideology behind sexual charges was an attempt of women gender degradation and deprivation of their right on equality and emancipation. The gender differentiated treatment of collaboration was an attempt to re-establish male dominance and traditional gender roles. 